\title{
PEMANFAATAN INTERNET OLEH PENYULUH PERTANIAN
}

\author{
(The Utilization of the Internet by Agricultural Extension Worker) \\ Putri Eksanika $^{1)}$ dan Sutisna Riyanto ${ }^{1)}$ \\ ${ }^{1)}$ Departemen Sains Komunikasi dan Pengembangan Masyarakat, Fakultas Ekologi Manusia, Institut \\ Pertanian Bogor, Darmaga Bogor 16680, Indonesia \\ Email: eksanika@gmail.com; sutisnari@apps.ipb.ac.id
}

\begin{abstract}
The development of information technology and communication is increasingly perceived by the public, one of them internet. Agricultural extension worker as the spearhead of agricultural development has an important role in assisting the development of agriculture. Internet as a medium that stores a variety of information on agriculture and as a medium of communication can be used to support the agricultural extension activities. The purpose of this study is to analyze the understanding of agricultural extension worker to the internet, analyze the behavior of internet usage by agricultural extension worker, and analyze the utilization of the internet by agricultural extension worker. This study was conducted using a quantitative approach that is supported by qualitative data. Quantitative data collected using questionnaires to 16 people from the agricultural extension worker of BP3K Dramaga and 22 people from the agricultural extension worker of BP3K Cibungbulang, the qualitative data obtained through interviews and observations. Obtained data analyzed using descriptive analysis and correlation tests. The results showed that agricultural extensions worker is sufficient used the internet to support in agricultural extension activities.
\end{abstract}

Keywords: information technology, communication, agricultural extension

\begin{abstract}
ABSTRAK
Perkembangan teknologi informasi dan komunikasi semakin dirasakan oleh masyarakat, salah satunya internet. Penyuluh pertanian sebagai ujung tombak pembangunan pertanian memiliki peran penting dalam membantu perkembangan pertanian. Internet sebagai media yang menyimpan berbagai informasi tentang pertanian dan sebagai media komunikasi dapat digunakan untuk mendukung kegiatan penyuluhan pertanian. Tujuan dari penelitian ini adalah untuk menganalisis pemahaman penyuluh pertanian pada internet, menganalisis perilaku penggunaan internet oleh penyuluh pertanian, dan menganalisis pemanfaatan internet oleh penyuluh pertanian. Penelitian ini dilakukan dengan menggunakan pendekatan kuantitatif yang didukung oleh data kualitatif. Data kuantitatif dikumpulkan dengan menggunakan kuesioner untuk 16 orang dari penyuluh pertanian dari BP3K Dramaga dan 22 orang dari penyuluh pertanian dari BP3K Cibungbulang, data kualitatif diperoleh melalui wawancara dan observasi. Data yang diperoleh dianalisis menggunakan analisis deskriptif dan uji korelasi. Hasil penelitian menunjukkan bahwa penyuluh pertanian telah cukup menggunakan internet untuk mendukung kegiatan penyuluhan pertanian.
\end{abstract}

Kata kunci: teknologi informasi, komunikasi, penyuluhan pertanian 


\section{PENDAHULUAN}

Pembangunan pertanian saat ini lebih ditekankan pada peningkatan kualitas sumberdaya manusia. Keberhasilan pembangunan pertanian antara lain ditentukan oleh kemampuan sumberdaya manusia dalam mengelola sistem pertanian yang sesuai dengan perkembangan ilmu pengetahuan dan teknologi. Upaya-upaya pembangunan pertanian tidak terlepas dari peran strategis penyuluh pertanian sebagai pihak yang menjembatani sistem sosial informasi dengan sistem sosial masyarakat petani, hal tersebut semakin menegaskan pentingnya peran penyuluh pertanian. Penyuluhan pertanian di Indonesia diatur melalui UU Nomor 16 Tahun 2006 tentang Sistem Penyuluhan Pertanian, Perikanan, dan Kehutanan ${ }^{1}$ yang menjadi landasan hukum dalam penyelenggaraan penyuluhan dan menjadi pilar kebangkitan penyuluhan yang sesuai untuk mensejahterakan masyarakat. Tenaga penyuluh merupakan ujung tombak pelaksanaan penyuluhan karena berhadapan langsung dengan masyarakat di lapangan.

Memasuki era globalisasi dan sejalan dengan pesatnya perkembangan ilmu pengetahuan dan teknologi, peranan informasi dalam pembangunan pertanian menjadi sangat penting. Teknologi memegang peranan penting dalam pembangunan pertanian. Salah satu contoh teknologi informasi dan komunikasi yang berkembang pesat saat ini yaitu internet. Internet menawarkan alternatif baru dalam memperoleh informasi dan sekaligus menyebarluaskan informasi.

Melalui pemanfaatan internet, penyuluh pertanian dapat belajar dalam meningkatkan kemampuannya untuk mengimbangi perubahan yang terjadi dalam masyarakat khususnya petani. Dengan berbagai manfaat yang diberikan oleh internet, internet dapat dimanfaatkan oleh penyuluh pertanian untuk mendukung kegiatan penyuluhan pertanian, mengingat khalayak pengguna internet saat ini sudah merambah sampai ke pedesaan. Oleh karena itu, menarik untuk dilakukan pengkajian

\footnotetext{
${ }^{1}$ http://www.bpkp.go.id/uu/filedownload/2/37/193.b pkp
}

mengenai pemanfaatan internet oleh penyuluh pertanian.

Berdasarkan latar belakang di atas, masalah penelitian adalah sebagai berikut:

1. Sejauhmana pemahaman penyuluh terhadap internet?

2. Bagaimana perilaku penggunaan internet oleh penyuluh pertanian?

3. Sejauhmana pemanfaatan internet oleh penyuluh pertanian?

Berdasarkan masalah penelitian di atas, tujuan penelitian adalah sebagai berikut:

1. Menganalisis pemahaman penyuluh pertanian terhadap internet.

2. Menganalisis perilaku penggunaan internet oleh penyuluh pertanian.

3. Menganalisis pemanfaatan internet oleh penyuluh pertanian.

\section{PENDEKATAN TEORITIS}

\section{Penyuluhan Pertanian}

Padmanagara dalam Hafsah (2009) telah menyatakan bahwa penyuluhan pertanian sebagai sistem pendidikan luar sekolah (non formal) untuk para petani dan keluarganya (ibu tani, pemuda tani) dengan tujuan agar mereka mampu, sanggup dan berswadaya memperbaiki/meningkatkan kesejahteraannya sendiri serta masyarakatnya. Penyuluh menurut Hasmosoewignjo dan Garnadi dikutip oleh Hafsah (2009) adalah seorang pendidik dan pembimbing masyarakat tani. Sebagai seorang mubaligh atau seorang missionair, seorang penyuluh pertanian harus mempunyai panggilan terhadap pekerjaannya, harus mempunyai citacita atau ideologi. Abbas dikutip oleh Hafsah (2009) menyatakan sebagai pendidik nonformal penyuluh pertanian dapat menampilkan dirinya sebagai penasehat, komunikator, dan motivator dalam rangka proses alih ilmu dan teknologi, pembinaan keterampilan serta pembentukan sikap yang sesuai dengan nilainilai dasar dan kebutuhan masyarakat dinamis yang membangun.

\section{Tugas dan Fungsi Penyuluh Pertanian}

Adapun Mosher yang dikutip oleh Mugniesyah (2006) menyatakan bahwa proses penyuluhan 
adalah bekerja dengan masyarakat pedesaan melalui pendidikan luar sekolah, sejalan dengan minat dan kebutuhan mereka yang erat hubungannya untuk memperoleh penghidupan, memperbaiki tingkat kehidupan keluarga pedesaan secara fisik serta mengangkat kesjahteraan masyarakat pedesaan. Tujuan utama pelayanan penyuluhan pertanian adalah untuk memberi keluarga petani berupa pengetahuan dan keterampilan baru yang bersesuaian dengan minat dan kebutuhan mereka yang erat hubungannya dengan upaya meningkatkan produksi usahatani mereka dan memperbaiki tingkat hidup keluarga petani.

\section{Metode dan Media Penyuluhan Pertanian}

Dalam melaksanakan kegiatan penyuluhan agar pesan yang disampaikan dapat diterima dengan baik perlu menggunakan metode yang sesuai dengan target penyuluhan. Maunder dikutip oleh Hafsah (2009) menggolongkan metode penyuluhan pertanian menjadi tiga berdasarkan jumlah sasaran yang akan dicapai, yaitu:

1. Metode perorangan, yakni penyuluh pertanian berhubungan secara langsung maupun tidak langsung dengan sasaran secara perorangan dimana kegiatan ini dilaksanakan antara lain dengan metode kunjungan rumah, kunjungan ke lahan usahatani, surat menyurat, dan lain sebagainya.

2. Metode kelompok, yakni penyuluh pertanian berhubungan dengan sekelompok orang untuk menyampaikan pesannya, metode penyuluhan dilaksanakan dengan ceramah, demonstrasi, karya wisata, temu lapang dan lain sebagainya.

3. Metode massa, yakni penyuluh pertanian menyampaikan pesan-pesan penyuluhan melalui media massa antara lain radio, televisi, surat kabar, rapat umum, pameran, dan sebagainya.

Merujuk kembali pada Hafsah (2009), media penyuluhan sebagai unsur penting dalam pelaksanaan penyuluhan berfungsi memperjelas materi penyuluhan yang akan disampaikan agar mudah diingat dan dipahami masyarakat sasarannya. Media penyuluhan merupakan alatalat atau perlengkapan penyuluhan yang diperlukan untuk memperlancar proses mengajar selama kegiatan penyuluhan tersebut dilaksanakan. Berdasarkan sumbernya dikenal adanya media hidup dan media mati. Media hidup merupakan media yang memanfaatkan manusia dan media mati adalah alat-alat seperti radio, televisi, koran, dan sejenisnya.

\section{Internet}

Merujuk pada Bungin (2008) lahirnya era komunikasi interaktif ditandai dengan terjadinya diversifikasi teknologi informasi dengan bergabungnya telepon, radio, komputer, dan televisi menjadi satu dan menandai teknologi yang disebut dengan internet. Menurut Severin dan Tankard (2011) internet pada dasarnya merupakan sebuah jaringan antar-komputer yang saling berkaitan. Jaringan ini tersedia secara terus-menerus sebagai pesanpesan elektronik, termasuk email, transmisi file, dan komunikasi dua arah antar-individu atau komputer. Merujuk pada pendapat Laquey yang dikutip oleh Ardianto et al. (2014), internet merupakan jaringan longgar dari ribuan komputer yang menjangkau jutaan orang di seluruh dunia.

\section{Pemanfaatan Internet}

Internet berkembang pesat tidak terlepas dari kegunaan atau manfaat yang diberikan oleh internet. Merujuk pada Muljono (2005) internet sebagai media komunikasi memiliki delapan macam kegunaan, yaitu:

1. Internet sebagai media mencari informasi dengan tanpa batasan. Segala hal dapat dicari dengan menggunakan mesin pencari 'search engine'.

2. Internet sebagai tempat untuk mengirim surat elektronik.

3. Internet merupakan media untuk mentransfer data komputer atau pemindahan data antar komputer. Jika data tersebut dimasukan ke dalam homepage (upload) maka setiap orang dapat mentransfer data tersebut ke komputer pribadi (download).

4. Bebasnya ruang internet sehingga orang dapat berlalu lalang di dalamnya.

5. Forum diskusi dan komunikasi.

6. Perangkat keras dan lunak diperlukan oleh pengguna internet.

7. Browser merupakan media untuk menampilkan citra gambar sebuah homepage atau website. 
8. Surat kabar digital atau biasa disebut sebagai media online memiliki kekuatan yang tanpa batas. Dengan mesin pencari, pengguna dapat mencari informasi yang diperlukan. Karenanya tidak ada informasi yang terbuang. Informasi dapat digunakan kapan saja, tidak terkait oleh waktu terbit edisi atau jam program, hanya bergantung pada kapan pengguna mau mengakses.

\section{Perilaku Penggunaan Internet}

Perilaku dalam menggunakan internet dapat ditunjukkan dari aspek yang mendukungnya. Djohari sebagaimana dikutip oleh Andina (2006) membagi aspek-aspek tersebut menjadi tiga, yaitu motif yang menjadi latar belakang penggunaan, durasi penggunaan dan frekuensi penggunaan.

Andina (2006) menjelaskan lebih lanjut motif seseorang dalam menggunakan internet dibagi menjadi tiga yaitu motif hiburan, sosial, dan pengetahuan. Motif hiburan memungkinkan pengguna untuk mencari kesenangannya di dunia maya misalnya mendengarkan musik dan melihat cuplikan (trailer) film layar lebar. Motif sosial mengacu pada hubungan sosial. Pengguna dapat mengembangkan pergaulannya tidak hanya dalam satu negara, bahkan di seluruh dunia dengan menggunakan fasilitas email dan chatting, sedangkan motif pengetahuan mengacu pada kegiatan mencari informasi untuk mendapatkan informasi/pengetahuan yang dibutuhkan pengguna.

Mengacu pada Andina (2006) durasi penggunaan internet mengacu pada lamanya seseorang dalam menggunakan internet. Durasi diduga juga dipengaruhi oleh motif seseorang dalam menggunakan internet, jaringan hubungan internet (internet network), dan biaya menggunakan internet. Motif mengacu pada tujuan mengakses internet. Apabila motif terpenuhi, maka durasi penggunaan internet pun akan lebih lama. Jaringan internet mengacu pada lamanya proses pada internet untuk mengakses informasi yang diinginkan/ dibutuhkan pengguna. Dalam hal biaya, penggunaan internet di rumah atau di warung internet (warnet) memerlukan biaya yang tidak sedikit. Semakin besar penggunaan, maka semakin besar pula biaya penggunaan internet.

Salah satu variabel (Andina 2006) mempengaruhi akses internet adalah frekuensi. Frekuensi diartikan seberapa sering atau berapa kali seseorang menggunakan internet (terkait dengan penggunaan internet dalam suatu periode tertentu). Tidak begitu berbeda dengan durasi, frekuensi pun juga diduga dipengaruhi oleh motif menggunakan internet, jaringan hubungan internet dan biaya penggunaan internet. seperti halnya durasi, frekuensi juga merupakan experiental elements dalam penggunaan internet.

\section{Kerangka Pemikiran}

Pemanfaatan internet oleh penyuluh pertanian dilihat pada pemanfaatan internet yang sudah dilakukan oleh penyuluh pertanian dan diukur berdasarkan tugas atau fungsi penyuluh pertanian, yaitu analisis situasi, penyadaran masalah, meningkatkan pengetahuan, membantu dalam pengambilan keputusan, serta meningkatkan motivasi dan keterampilan. Pemanfaatan internet akan terjadi jika penyuluh memiliki perilaku dalam menggunakan internet. Perilaku penggunaan internet ditunjukan berdasarkan durasi dan frekuensi. Aspek-aspek tersebut dapat mengidentifikasi perilaku penggunaan internet oleh penyuluh pertanian. Perilaku penggunaan internet bervariasi, karena setiap penyuluh pertanian memiliki karakteristik dan motivasi penggunaan internet yang berbeda, dan juga perilaku penggunaan internet tergantung kepada apa yang dipahami penyuluh mengenai internet. Karakteristik penyuluh diantaranya usia, jenis kelamin, pendidikan, pendapatan, serta kepemilikan media komunikasi dan informasi. Motivasi penggunaan internet diantaranya kebutuhan informasi, kebutuhan diterima secara sosial, serta kebutuhan hiburan. Keterkaitan berbagai variabel tersebut dapat dilihat pada gambar berikut: 


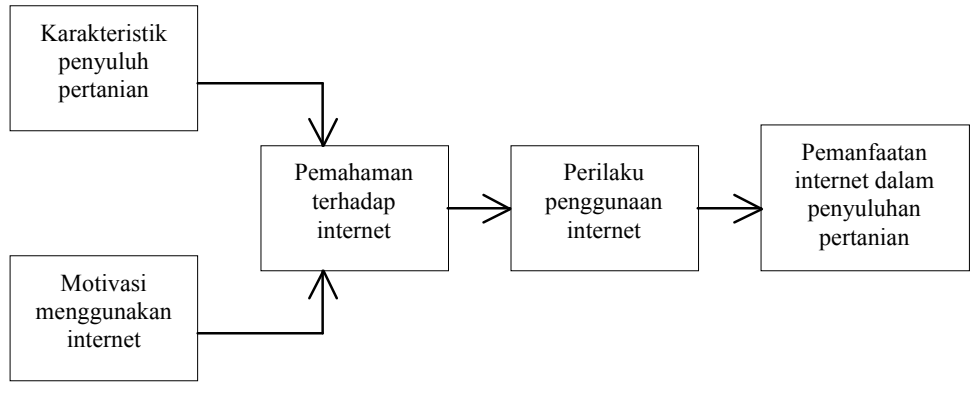

Keterangan:

$$
\rightarrow \text { : hubungan }
$$

Gambar 1 Kerangka pemikiran

\section{Hipotesis Penelitian}

Hipotesis penelitian adalah sebagai berikut:

1. Diduga terdapat hubungan antara karakteristik penyuluh (usia, jenis kelamin, pendidikan formal, pendidikan non-formal, pendapatan, serta kepemilikan media komunikasi dan informasi) dengan pemahaman penyuluh terhadap internet.

2. Diduga terdapat hubungan antara motivasi penggunaan internet dengan pemahaman penyuluh terhadap internet.

3. Diduga terdapat hubungan antara pemahaman penyuluh terhadap internet dengan perilaku penggunaan internet.

4. Diduga terdapat hubungan antara perilaku penggunaan internet dengan pemanfaatan internet oleh penyuluh pertanian.

\section{PENDEKATAN LAPANG}

Penelitian ini menggunakan pendekatan kuantitatif, didukung dengan data kualitatif. Pendekatan kuantitatif dilakukan dengan metode survey yaitu penelitian yang mengambil sampel dari satu populasi dan menggunakan kuesioner sebagai alat pengumpulan data (Singarimbun 1989). Unit analisis dari penelitian ini adalah individu.

Penelitian ini dilaksanakan di dua wilayah di Kabupaten Bogor yakni wilayah Dramaga dan Cibungbulang. Pemilihan lokasi ini dilakukan secara sengaja (purposive) dengan pertimbangan bahwa wilayah Dramaga sudah memiliki jaringan internet yang baik karena dekat dengan kota, serta wilayah Dramaga mempunyai tingkat aksesibilitas tinggi terhadap sumber informasi pertanian, mengingat terdapatnya unit kerja penelitian dalam bidang pertanian dan perguruan tinggi yang menyediakan banyak informasi mengenai perkembangan dalam bidang pertanian yang kemudian informasi tersebut sebagian diunggah di internet. Pemilihan wilayah Cibungbulang dilakukan dengan pertimbangan bahwa wilayah kerja para penyuluh pertanian di wilayah Cibungbulang lebih beragam, maka akan terlihat perbedaan dari setiap penyuluh mengenai akses terhadap internet. Penelitian di lapangan dilakukan selama 3 minggu, yaitu pada bulan Maret hingga April 2015.

Populasi pada penelitian ini adalah penyuluh pertanian yang berada di Kabupaten Bogor. Responden pada penelitian ini adalah penyuluh pertanian di wilayah Dramaga dan Cibungbulang, Kabupaten Bogor. Responden berjumlah 38 orang penyuluh pertanian, wilayah Dramaga 16 orang dan wilayah Cibungbulang 22 orang, baik penyuluh yang berstatus sebagai Pegawai Negeri Sipil (PNS) ataupun non-PNS. Metode pengambilan data yang digunakan ialah secara sensus. Informan yang dipilih adalah pihak Badan Ketahanan Pangan dan Pelaksanaan Penyuluhan Pertanian, Perikanan, dan Kehutanan (BKP5K) Kabupaten Bogor yang menangani dan memahami tentang aktivitas penyuluhan yang terjadi di Kabupaten Bogor secara keseluruhan.

Jenis data yang dikumpulkan adalah data primer dan data sekunder. Data primer diperoleh langsung dari sumber data dengan menggunakan teknik sebagai berikut wawancara terstruktur, wawancara terbuka dan mendalam kepada informan, dan observasi. Data sekunder diperoleh melalui studi literatur terhadap data monografi wilayah dan literatur lainnya yang relevan dengan penelitian ini.

Analisis deskriptif dilakukan untuk mendeskripsikan keragaman karakteristik penyuluh pertanian, motivasi menggunakan internet, pemahaman internet, perilaku penggunaan internet, dan pemanfaatan internet oleh penyuluh pertanian. Beberapa prosedur statistika yang digunakan meliputi rataan, standar deviasi, nilai maksimum, nilai minimum, dan frekuensi. Analisis hubungan dilakukan untuk menguji hubungan antara 
variabel penelitian, dengan menggunakan prosedur korelasi Rank-Spearman dan ChiSquare.

\section{GAMBARAN LOKASI PENELITIAN}

\section{BP3K Wilayah Dramaga}

BP3K Wilayah Dramaga beralamat di Jalan Raya Sindang Barang No. 130 Kota Bogor. Wilayah kerja BP3K Dramaga mencakup Kecamatan Dramaga, Kecamatan Ciomas, dan Kecamatan Tamansari. Total penyuluh yang bertugas di BP3K Wilayah Dramaga berjumlah 19 orang yang terdiri dari 1 orang ketua balai, 8 orang Pegawai Negeri Sipil (PNS), 8 orang non PNS (THL-TBPP dan THL P2BN), serta 1 orang bertugas sebagai Out Sourcing. Penyuluh yang bertugas pada bidang pertanian berjumlah 16 orang yang terdiri dari 8 orang PNS dan 8 orang non PNS. Demi tercapainya pelaksanaan tugas dan fungsinya, BP3K Wilayah Dramaga didukung dan dilengkapi dengan fasilitas gedung atau kantor kerja, aula pertemuan, dan lahan sebagai tempat percobaan atau pembelajaran. Aula pertemuan digunakan sebagai tempat untuk melaksanakan program penyuluhan dengan para petani, setiap balai memiliki jadwal rutin pertemuan setiap dua minggu sekali. BP3K Wilayah Dramaga pun dilengkapi dengan fasilitas komputer dan jaringan internet yang memadai, dan juga setiap balai penyuluhan sudah mempunyai website dan juga akun facebook sebagai media untuk bertukar informasi.

\section{BP3K Wilayah Cibungbulang}

BP3K Wilayah Cibungbulang beralamat di Jalan Kapten Basuki Bakri, Cibeureum, Desa Cibatok, Kecamatan Cibungbulang, Kabupaten Bogor. BP3K Wilayah Cibungbulang mencakup wilayah kerja atau wilayah binaan di Kecamatan Cibungbulang, Kecamatan Pamijahan, Kecamatan Ciampea, dan Kecamatan Tenjolaya. Total penyuluh yang bertugas di BP3K Wilayah Cibungbulang berjumlah 24 orang yang terdiri dari 1 orang ketua balai, 8 orang PNS, 14 orang non PNS, serta 1 orang bertugas sebagai Out Sourcing. Penyuluh yang bertugas pada bidang pertanian berjumlah 22 orang yang terdiri dari 8 orang
PNS dan 14 orang non PNS. BP3K Wilayah Cibungbulang untuk mencapai tugas dan fungsinya dilengkapi dengan fasilitas gedung atau kantor kerja serta aula pertemuan. Aula pertemuan digunakan sebagai tempat untuk melaksanakan program penyuluhan dengan para petani, setiap balai memiliki jadwal rutin pertemuan setiap dua minggu sekali.

\section{GAMBARAN UMUM RESPONDEN}

\section{Motivasi Menggunakan Internet}

Tabel 1 menyajikan mengenai tingkat motivasi responden dalam menggunakan internet. Keseluruhan responden sudah termotivasi untuk menggunakan internet, meskipun motivasi yang dimiliki responden belum kuat. Hal tersebut terlihat pada Tabel 1 bahwa total rataan skor pada ketiga indikator di atas adalah sebesar 3,84 yang artinya kebanyakan responden sudah memiliki motivasi untuk menggunakan internet tetapi motivasi tersebut belum kuat. Responden yang sudah memiliki motivasi merupakan responden yang sudah sadar akan teknologi.

Tabel 1 Persentase dan rataan skor responden menurut motivasi menggunakan internet

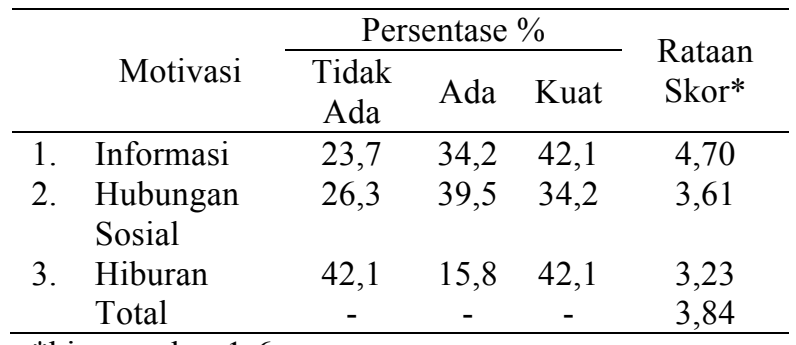

*kisaran skor 1-6

Merujuk pada pendapat Rakhmat (2003) kita menggunakan media massa karena didorong oleh motif-motif tertentu dan ada berbagai kebutuhan yang dipuaskan oleh media massa. Fungsi media massa yaitu untuk memenuhi kebutuhan akan informasi dan hiburan. Individu mempunyai kebebasan untuk memilih isi media, media massa memberikan banyak peluang untuk memenuhi kebutuhan.

\section{Informasi}

Motivasi kebutuhan informasi adalah alasan responden dalam menggunakan internet berupa 
pencarian informasi untuk kegiatan penyuluhan, pendukung tugas, atau pemecahan masalah. Rataan skor pada indikator ini berjumlah 4,70 yang artinya dalam hal ini, responden sudah memiliki motivasi untuk mencari informasi melalui internet tetapi motivasi yang dimiliki oleh responden tidak kuat. Motivasi akan kebutuhan informasi merupakan motivasi yang paling besar dirasakan oleh responden, karena responden pada penelitian ini merupakan seorang penyuluh yang dituntut untuk terus mengembangkan pengetahuan mereka. Maka dari itu, salah satu cara responden untuk memenuhi kebutuhan informasi adalah dengan cara mencari informasi-informasi terkait bidang pekerjaan mereka melalui internet.

Responden sudah menyadari bahwa internet merupakan suatu media yang dapat digunakan untuk mencari berbagai macam informasi dan responden sudah mengetahui bahwa internet menyediakan search engine untuk memudahkan penggunanya dalam memenuhi kebutuhan untuk menambah wawasan dan mencari jawaban apabila responden memiliki hal-hal yang belum diketahui sebelumnya. Seperti yang dikemukakan oleh Yusup (2009) menjelaskan bahwa informasi dengan segala jenis dan sifatnya hampir tanpa putus selama 24 jam sehari menerpa kita melalui saluran-saluran komunikasi seperti televisi, telepon seluler, majalah, surat kabar, film, dan internet. internet sebagai media komunikasi yang baru, bahkan lebih bebas lagi tidak pernah putus sepanjang waktu, informasi yang disediakan pun relatif tidak terbatas, justru yang terbatas adalah waktu dan umur kita untuk memanfaatkannya.

\section{Hubungan Sosial}

Motivasi hubungan sosial adalah alasan menggunakan internet berupa keinginan untuk membina hubungan, memperluas jaringan, dan diterima oleh sesama penyuluh. Rataan skor pada indikator ini berjumlah 3,61 yang artinya pada indikator ini, responden sudah memiliki atau sudah ada di dalam dirinya motivasi untuk menggunakan internet sebagai media untuk berhubungan atau berkomunikasi dengan orang lain atau dengan sesama penyuluh, tetapi motivasi tersebut tidak kuat.
Responden yang relatif berusia muda, lebih sering menggunakan internet karena ada dorongan untuk tetap update dan menjalin komunikasi dengan kerabat melalui internet salah satunya melalui media sosial.

\section{Hiburan}

Motivasi hiburan adalah alasan menggunakan internet berupa keinginan mengisi waktu luang, menyalurkan hobi, menghilangkan stres, dan sebagainya. Rataan skor pada indikator ini berjumlah 3,23 yang artinya responden sudah memiliki motivasi dalam diri responden untuk mencari hiburan melalui internet, walaupun motivasi tersebut belum kuat.

Hal ini menunjukkan bahwa sebagian responden sudah memiliki motivasi yang kuat untuk mencari hiburan melalui internet, seperti mengunduh lagu atau video, menulis blog, dan mencari berita-berita hiburan. Selain itu sebagian responden tidak memiliki motivasi untuk menggunakan internet sebagai hiburan karena menurut sebagian responden isi dari internet membawa dampak negatif, seperti halnya pornografi.

\section{PEMAHAMAN INTERNET}

\section{Tingkat Pemahaman Internet}

Pemahaman responden mengenai internet adalah tingkat pengetahuan responden mengenai pengertian internet, fungsi internet, media untuk mengakses internet, cara atau teknis menggunakan internet, dan penggunaan internet. Tabel 2 menyajikan mengenai pemahaman responden terhadap internet.

Keseluruhan responden sudah paham tentang bagaimana memanfaatkan internet. Hal ini dapat dilihat pada Tabel 2 bahwa total rataan skor pada kelima indikator di atas adalah sebesar 4,80 yang artinya sebagian besar responden sudah cukup paham mengenai internet. 
Tabel 2 Persentase dan rataan skor responden menurut pemahaman terhadap internet

\begin{tabular}{llcccc}
\hline \multirow{2}{*}{ Pemahaman } & \multicolumn{3}{c}{ Persentase \% } & \multirow{2}{*}{ Rataan Skor* } \\
\cline { 3 - 5 } & & $\begin{array}{c}\text { Tidak } \\
\text { Tahu }\end{array}$ & $\begin{array}{c}\text { Paham } \\
\text { Sebagian }\end{array}$ & Paham & \\
\hline 1. & Pengertian internet & 31,6 & 13,2 & 55,3 & 3,85 \\
2. & Fungsi internet & 15,8 & 31,6 & 52,6 & 4,72 \\
3. & Media untuk mengakses internet & 0 & 23,7 & 76,3 & 5,19 \\
4. & Cara atau teknis menggunakan internet & 0 & 15,8 & 84,2 & 5,18 \\
5. & Penggunaan internet & 0 & 28,9 & 71,1 & 5,06 \\
\hline & Total & - & - & - & 4,80 \\
\hline
\end{tabular}

*kisaran skor 1-6

\section{Pengertian Internet}

Pemahaman responden mengenai pengertian internet merupakan pengetahuan responden mengenai maksud dari adanya internet. Pada Tabel 4 rata-rata responden sudah memahami pengertian internet yaitu sebanyak 55,3 persen responden dengan rataan skor 3,85 hal ini dikarenakan perkembangan teknologi informasi dan komunikasi yang pesat menyebabkan internet semakin dikenal dan menjadi suatu hal yang tidak asing dikalangan masyarakat, bahkan internet sudah menjadi kebutuhan sehari-hari.

\section{Fungsi Internet}

Pemahaman responden mengenai fungsi dari internet merupakan pengetahuan responden mengenai fasilitas yang ada di internet. Tabel 4 menunjukkan sebagian besar responden sudah memahami fungsi internet, hal tersebut ditunjukkan dengan persentase sebesar 52,6 persen. Rataan skor sebesar 4,72 menunjukkan bahwa responden sudah memahami fungsi dari internet. Hal tersebut dikarenakan internet merupakan media yang sudah menjadi kebutuhan sehari-hari masyarakat sehingga responden telah mengetahui dan memahami fungsi internet sebelum mengaksesnya. Responden mengakses internet berdasarkan pemahaman mereka bahwa internet berfungsi sebagai tempat untuk mencari informasi dan menambah wawasan karena diinternet terdapat berbagai situs-situs terkait dengan pekerjaan responden sebagai penyuluh pertanian dan internet pun memiliki berbagai situs-situs untuk hiburan seperti facebook dan lainnya.

\section{Media Akses Internet}

Pemahaman responden mengenai media akses internet merupakan pengetahuan responden terkait media untuk mengakses internet. Tabel 4 menunjukkan sebanyak 76,8 persen responden sangat paham bahwa untuk mengakses internet butuh media pendukung, seperti laptop atau handphone yang memiliki fitur untuk mengakses internet. Rataan skor sebesar 5,19 menunjukkan bahwa responden sudah sangat paham bahwa untuk mengakses internet butuh media pendukung seperti laptop dan handphone yang memiliki fitur untuk mengakses internet. Berdasarkan hasil observasi dilapang, responden di kedua wilayah sebagian besar sudah memiliki handphone dengan fitur internet dan juga laptop, serta internet sudah menjadi hal lumrah bagi para responden, maka dari itu responden sudah sangat memahami mengenai media akses internet.

\section{Teknis Menggunakan Internet}

Pemahaman responden mengenai teknis menggunakan internet merupakan pengetahuan responden terkait cara untuk mengakses internet. Dapat dilihat pada Tabel 2 sebanyak 84,2 persen responden sudah memahami teknis menggunakan internet. Rataan skor yang didapatkan adalah sebesar 5,18 hal tersebut menunjukkan bahwa sebagian besar responden sudah sangat paham mengenai teknis menggunakan internet, bahwa saat mengakses internet perlu didukung dengan jaringan yang baik dan responden juga sudah paham bawa mengakses internet tidak sulit.

\section{Penggunaan Internet}

Pemahaman responden mengenai penggunaan internet merupakan pengetahuan responden terkait manfaat yang diberikan oleh internet ketika responden mengakses internet. Tabel 4 menunjukkan sebagian besar responden sudah sangat paham mengenai penggunaan internet, terlihat dari persentasenya sebesar 71,1 persen dengan rataan skor sebesar 5,06 yaitu responden 
sudah memahami bahwa internet memberikan kemudahan bagi penggunanya untuk berkomunikasi dan mencari informasi, dan juga diinternet tidak hanya mendapatkan informasi tetapi juga bisa menyebarluaskan informasi melalui fitur upload file.

\section{Hubungan Karakteristik Penyuluh Pertanian dengan Pemahaman Internet}

Hubungan antara karakteristik penyuluh pertanian dengan pemahaman internet dianalisis dengan menggunakan koefisien chi square dan Rank Spearman ditunjukkan pada Tabel 3.

Tabel 3 Nilai koefisien korelasi Rank Spearman dan chi square berdasarkan hubungan antara karakteristik penyuluh pertanian dengan pemahaman internet

\begin{tabular}{lcccccc}
\hline \multirow{2}{*}{$\begin{array}{c}\text { Karakteristik } \\
\text { Penyuluh } \\
\text { Pertanian }\end{array}$} & $\begin{array}{c}\text { Koe } \\
\text { fisien }\end{array}$ & $\begin{array}{c}\text { Pengertian } \\
\text { Internet }\end{array}$ & $\begin{array}{c}\text { Fungsi } \\
\text { Internet }\end{array}$ & $\begin{array}{c}\text { Media } \\
\text { Akses } \\
\text { Internet }\end{array}$ & $\begin{array}{c}\text { Teknis } \\
\text { Penggunaan } \\
\text { Internet }\end{array}$ & $\begin{array}{c}\text { Penggunaan } \\
\text { Internet }\end{array}$ \\
\hline Usia & $\gamma_{\mathrm{s}}$ & $-0,377^{* *}$ & $-0,543^{* *}$ & $-0,385^{*}$ & $-0,076$ & $-0,334^{*}$ \\
Jenis kelamin & $\chi^{2}$ & 4,028 & 1,255 & 1,083 & 0,038 & 5,124 \\
& $\mathrm{c}$ & 0,310 & 0,179 & 0,166 & 0,031 & 0,345 \\
$\begin{array}{l}\text { Pendidikan } \\
\text { formal }\end{array}$ & $\gamma_{\mathrm{s}}$ & $-0,205$ & $-0,214$ & $-0,131$ & $-0,102$ & $-0,150$ \\
$\begin{array}{l}\text { Pendidikan non } \\
\text { formal }\end{array}$ & $\gamma_{\mathrm{s}}$ & $-0,252$ & $-0,392^{*}$ & $-0,362^{*}$ & $-0,025$ & $-0,218$ \\
$\begin{array}{l}\text { Pendapatan } \\
\text { Kepemilikan } \\
\text { media }\end{array}$ & $\gamma_{\mathrm{s}}$ & $-0,250$ & $-0,296$ & $-0,133$ & $-0,135$ & $-0,324^{*}$ \\
\hline 1 & $\gamma_{\mathrm{s}}$ & 0,112 & 0,092 & 0,013 & 0,167 & 0,241 \\
\hline
\end{tabular}

${ }^{1} \gamma_{\mathrm{s}}=$ koefisien Rank Spearman, $\chi^{2}=$ koefisien Chi Square

$*=$ hubungan nyata $(\mathrm{p}<0,05)$ dan $* *=$ hubungan sangat nyata $(\mathrm{p}<0,01)$

Hubungan karakteristik penyuluh pertanian dengan pemahaman internet menunjukkan nilai koefisien korelasi yang berada pada tingkat keeratan rendah $\left(\gamma_{\mathrm{s}}=0,30-0,50\right)$ dan keeratan sedang $\left(\gamma_{\mathrm{s}}=0,50-0,70\right)$

Hasil analisis korelasi Rank Spearman pada Tabel 3 menunjukkan bahwa usia berhubungan nyata tetapi negatif atau berbanding terbalik terhadap pemahaman internet. Hal ini menunjukkan bahwa semakin tingginya usia responden maka pemahamannya dalam mengakses internet akan semakin kecil. Responden yang berusia lebih tua cenderung kurang memahami internet dibandingkan dengan responden yang berusia muda. Responden yang berusia muda lebih memahami internet karena intensitas mengakses internetnya lebih sering.

Tabel 3 dapat dilihat bahwa secara keseluruhan tidak terdapat perbedaan antara jenis kelamin dengan pemahaman internet. Hal tersebut dikarenakan hasil pengujian menunjukkan bahwa responden perempuan dan responden laki-laki sama-sama sudah paham internet. Saat ini internet sudah bukan lagi suatu hal yang asing, bahkan internet sudah menjadi bagian dari aktivitas keseharian masyarakat.

Tabel 3 menunjukkan bahwa tingkat pendidikan formal tidak berhubungan nyata dengan arah hubungan yang negatif atau berbanding terbalik. Hasil penelitian di lapang menunjukkan bahwa responden merupakan lulusan Sekolah Menengah Atas (SMA)/sederajat dan diploma atau perguruan tinggi. Pendidikan yang dimiliki oleh responden termasuk tinggi sehingga responden sudah cukup paham mengenai internet.

Tabel 3 menunjukkan bahwa sebagian besar hasil pengujian tingkat pendidikan non formal terhadap pemahaman internet tidak berhubungan nyata dengan arah negatif atau berbanding terbalik. Hal tersebut dikarenakan responden sudah memahami mengenai internet diluar dari kegiatan pelatihan yang responden ikuti. Hubungan nyata terlihat pada indikator pendidikan non formal dengan indikator 
pemahaman internet yaitu fungsi internet dan media akses internet, tetapi nilai korelasi yang ditunjukkan termasuk kriteria rendah.

Hasil analisis korelasi Rank Spearman antara pendapatan responden dengan pemahaman internet pada Tabel 3 secara keseluruhan menunjukkan tidak terdapat hubungan nyata dengan arah yang negatif. Hal tersebut menunjukkan bahwa semakin tinggi tingkat pendapatan responden maka tidak mempengaruhi pemahaman responden mengenai internet. Responden sudah memahami mengenai internet di luar dari pendapatan yang responden dapatkan setiap bulannya.

Tabel 3 menyajikan hasil pengujian Rank Spearman antara tingkat kepemilikan media komunikasi dan informasi dengan pemahaman internet, hasil uji tersebut menunjukkan tidak terdapat hubungan nyata antara kedua variabel tersebut. Hal ini dapat disimpulkan bahwa kepemilikan media komunikasi dan informasi untuk mengakses internet seperti handphone, laptop/netbook, komputer, dan iPad/Tab tidak dimanfaatkan secara maksimal untuk mengaskes internet.
Terlihat pada hasil uji signifikansi ternyata hanya karakteristik tertentu yang terbukti berhubungan dengan pemahaman internet. Karakteristik penyuluh pertanian yang berhubungan sangat nyata atau kuat $(\mathrm{p}<0,01)$ adalah usia dengan pengertian internet dan fungsi internet. Sedangkan karakteristik penyuluh pertanian yang berhubungan nyata $(\mathrm{p}<0,05)$ adalah usia dengan media akses internet dan penggunaan internet, pendidikan non formal dengan fungsi internet dan media akses internet, serta pendapatan dengan penggunaan internet. Hal ini membuktikan pula yakni hipotesis pertama yang menyatakan "Terdapat hubungan antara karakteristik penyuluh (usia, jenis kelamin, pendidikan formal, pendidikan non-formal, pendapatan, serta kepemilikan media komunikasi dan informasi) dengan pemahaman penyuluh terhadap internet" diterima.

\section{Hubungan Motivasi Menggunakan Internet dengan Pemahaman Internet}

Hubungan antara motivasi menggunakan internet dengan pemahaman internet dianalisis dengan menggunakan koefisien Rank Spearman ditunjukkan pada Tabel 4.

Tabel 4 Nilai koefisien korelasi Rank Spearman berdasarkan hubungan antara motivasi menggunakan internet dengan pemahaman internet

\begin{tabular}{lccccc}
\hline \multirow{2}{*}{$\begin{array}{c}\text { Motivasi Menggunakan } \\
\text { Internet }\end{array}$} & $\begin{array}{c}\text { Pengertian } \\
\text { Internet }\end{array}$ & $\begin{array}{c}\text { Fungsi } \\
\text { Internet }\end{array}$ & $\begin{array}{c}\text { Media } \\
\text { Akses } \\
\text { Internet }\end{array}$ & $\begin{array}{c}\text { Teknis } \\
\text { Menggunakan } \\
\text { Internet }\end{array}$ & $\begin{array}{c}\text { Penggunaan } \\
\text { Internet }\end{array}$ \\
\hline Informasi & 0,164 & $0,396^{*}$ & $0,369^{*}$ & 0,278 & $0,447^{* *}$ \\
Hubungan Sosial & $0,604^{* *}$ & $0,706^{* *}$ & 0,289 & 0,316 & $0,569^{* *}$ \\
Hiburan & $0,667^{* *}$ & $0,757^{* *}$ & 0,270 & 0,236 & $0,443^{* *}$ \\
\hline
\end{tabular}

$*=$ hubungan nyata $(\mathrm{p}<0,05)$ dan $* *=$ hubungan sangat nyata $(\mathrm{p}<0,01)$

Hasil pengujian Rank Spearman pada Tabel 4 secara keseluruhan menunjukkan hasil nilai koefisien korelasi pada tingkat korelasi rendah $\left(\gamma_{\mathrm{s}}=0,30-0,50\right)$ dan korelasi sedang atau moderat $\left(\gamma_{\mathrm{s}}=0,50-0,70\right)$. Hubungan nyata $(\mathrm{p}<$ $0,05)$ antara motivasi menggunakan internet dengan pemahaman internet ditunjukkan pada hubungan indikator informasi dengan fungsi internet dan media akses internet. Hal tersebut dikarenakan semakin tinggi keinginan responden untuk memenuhi kebutuhan informasi mereka, maka semakin tinggi pula pemahaman responden mengenai fungsi internet dan situs yang terdapat diinternet serta responden juga semakin memahami bahwa untuk memenuhi kebutuhan akan informasi tersebut bisa responden dapatkan melalui handphone dan laptop mereka.

Hubungan sangat nyata $(\mathrm{p}<0,01)$ antara motivasi menggunakan internet dengan pemahaman internet ditunjukkan pada hubungan indikator informasi dengan penggunaan internet, indikator 
hubungan sosial dengan pengertian internet, fungsi internet, dan penggunaan internet, serta indikator hiburan dengan pengertian internet, fungsi internet, dan penggunaan internet. Hal ini berarti semakin tinggi motivasi responden akan kebutuhan informasi, hubungan sosial, dan hiburan maka akan semakin tinggi pula pemahaman mengenai pengertian internet, fungsi yang diberikan oleh internet seperti situs-situs yang ada di internet dapat membantu responden untuk memenuhi kebutuhan informasi, sosial, dan hiburan mereka. Semakin tinggi motivasi yang dimiliki responden maka semakin tinggi pula pemahaman responden bahwa internet memiliki kegunaan sebagai media untuk berkomunikasi dan media untuk meng-upload atau men-download file.

Hasil pengujian membuktikan bahwa motivasi menggunakan internet berhubungan nyata dengan pemahaman internet. Hipotesis kedua yang berbunyi "terdapat hubungan antara motivasi penggunaan internet dengan pemahaman penyuluh terhadap internet" diterima. Hal ini menjelaskan bahwa pemahaman responden mengenai internet terjadi karena ada motivasi di dalam diri untuk menggunakan internet.

\section{PERILAKU PENGGUNAAN INTERNET}

\section{Frekuensi dan Durasi Penggunaan Internet}

Perilaku dalam menggunakan internet dapat ditunjukkan dari aspek yang mendukungnya. Aspek yang mendukung perilaku dalam menggunakan internet antara lain frekuensi dan durasi. Frekuensi mengacu pada pengertian seberapa sering atau berapa kali seseorang menggunakan internet. Frekuensi terkait dengan penggunaan internet dalam suatu periode tertentu, sedangkan durasi penggunaan internet mengacu pada lamanya seseorang dalam menggunakan internet. Tingkat perilaku penggunaan internet dapat dilihat pada Tabel 5 .

Tabel 5 Persentase dan rataan responden menurut frekuensi dan durasi penggunaan internet

\begin{tabular}{|c|c|c|c|c|c|c|}
\hline & Perilaku & & & rsentase & & \\
\hline & $\begin{array}{l}\text { Penggunaan } \\
\text { Internet }\end{array}$ & Media & Rendah & Sedang & Tinggi & Rataan \\
\hline 1. & Frekuensi & Handphone & 50,0 & 18,4 & 31,6 & 4,78 \\
\hline & & Komputer/laptop kantor & 81,6 & 15,8 & 2,6 & 0,73 \\
\hline & & Komputer/laptop rumah & 78,9 & 7,9 & 13,2 & 1,00 \\
\hline & & Total & - & - & - & 2,17 \\
\hline 2. & Durasi & Handphone & 71,1 & 23,7 & 5,3 & 2,73 \\
\hline & & Komputer/laptop kantor & 89,5 & 7,9 & 2,6 & 0,97 \\
\hline & & Komputer/laptop rumah & 78,9 & 18,4 & 2,6 & 1,57 \\
\hline & & Total & - & - & - & 1,75 \\
\hline
\end{tabular}

Sebagian besar responden sudah menggunakan internet yang ditunjukkan oleh frekuensi dan durasi responden saat menggunakan internet. Total rataan pada indikator frekuensi menunjukkan angka 2,17 yang artinya responden hanya menggunakan internet sebanyak 2 sampai 3 kali dalam satu hari. Total rataan pada indikator durasi menunjukkan angka 1,75 yang artinya responden hanya menggunakan internet sebanyak 1-2 jam dalam sehari. Perilaku penggunaan internet oleh responden pada penelitian ini masih dalam kategori rendah, yaitu tidak lebih dari 4 kali dan lebih dari 3 jam dalam satu hari. Hal tersebut juga dikarenakan waktu kerja responden sebagai penyuluh pertanian di lapang. Responden lebih banyak menghabiskan aktivitas di lapang untuk membantu petani, maka dari itu waktu yang dimiliki responden untuk menggunakan internet tidak banyak.

\section{Hubungan Pemahaman Internet dengan Perilaku Penggunaan Internet}

Hubungan antara pemahaman internet dengan perilaku penggunaan internet dianalisis dengan menggunakan koefisien Rank Spearman ditunjukkan pada Tabel 6 . 
Tabel 6 Nilai koefisien korelasi Rank Spearman berdasarkan hubungan antara pemahaman internet dengan perilaku penggunaan internet

\begin{tabular}{lcc}
\hline \multirow{2}{*}{ Pemahaman Internet } & \multicolumn{2}{c}{ Perilaku Penggunaan Internet } \\
\cline { 2 - 3 } & Frekuensi & Durasi \\
\hline Pengertian internet & $0,510^{* *}$ & $0,554^{* *}$ \\
Fungsi internet & $0,503^{* *}$ & $0,621^{* *}$ \\
Media akses internet & 0,092 & 0,283 \\
Teknis penggunaan internet & 0,003 & 0,024 \\
Penggunaan internet & $0,489^{* *}$ & $0,411^{* *}$ \\
\hline
\end{tabular}

$*=$ hubungan nyata $(\mathrm{p}<0,05)$ dan $* *=$ hubungan sangat nyata $(\mathrm{p}<0,01)$

Tabel 6 menunjukkan nilai koefisien korelasi antara pemahaman internet dengan perilaku penggunaan internet. Secara keseluruhan menunjukkan hasil nilai koefisien korelasi pada tingkat korelasi rendah $\left(\gamma_{\mathrm{s}}=0,30-0,50\right)$ dan korelasi sedang atau moderat $\left(\gamma_{\mathrm{s}}=0,50-0,70\right)$.

Hasil uji korelasi antara media akses internet dan teknis penggunaan internet dengan frekuensi dan durasi menunjukkan hasil yang tidak berhubungan. Hal tersebut dikarenakan responden sudah paham bahwa untuk mengakses internet membutuhkan media dan jaringan yang baik serta mengakses internet itu tidak sulit, dan hal tersebut juga tidak mempengaruhi seberapa seringnya responden menggunakan internet. Hasil uji korelasi menunjukkan hubungan sangat nyata $(\mathrm{p}<0,01)$ antara pemahaman internet dengan frekuensi dan durasi menggunakan internet. Hubungan sangat nyata tersebut terlihat pada indikator pengertian internet, fungsi internet, dan penggunaan internet dengan frekuensi dan durasi. Hal tersebut dikarenakan semakin tinggi pemahaman responden mengenai internet, maka semakin tinggi pula frekuensi responden saat mengakses internet dan semakin tinggi durasi responden saat mengakses internet. Semakin responden memahami bahwa diinternet terdapat berbagai situs yang bisa digunakan oleh responden dan internet merupakan sebuah media untuk berkomunikasi maka responden akan semakin sering menggunakan internet. Responden yang jarang menggunakan internet adalah responden yang pemahaman mengenai internetnya sedikit, seperti responden yang menggunakan internet hanya untuk browsing atau googling saja, padahal ada media sosial yang dapat mereka gunakan untuk berkomunikasi dengan keluarga atau rekan sesama penyuluh bahkan dapat digunakan untuk berkomunikasi dengan petani.

Hasil pengujian membuktikan bahwa hipotesis yang berbunyi "diduga terdapat hubungan antara pemahaman penyuluh terhadap internet dengan perilaku penggunaan internet" diterima.

\section{PEMANFAATAN INTERNET}

\section{Tingkat Pemanfaatan Internet}

Pemanfaatan internet adalah penggunaan internet melalui mesin pencarian yang dilakukan oleh responden untuk memenuhi kebutuhan informasinya. Pemanfaatan internet oleh penyuluh pertanian dilihat pada pemanfaatan internet yang sudah dilakukan oleh penyuluh pertanian dan pandangan penyuluh pertanian tentang potensi pemanfaatan internet untuk penyuluhan pertanian. Data ini diukur dengan melihat tugas atau fungsi penyuluh pertanian. Sebaran responden berdasarkan pemanfaatan internet dapat dilihat pada Tabel 7.

Berdasarkan Tabel 7 terlihat bahwa responden sudah memanfaatkan internet untuk mendukung kegiatan penyuluhan, terutama dalam hal meningkatkan pengetahuan dengan rataan skor yang tertinggi di antara kegiatan-kegiatan lainnya yaitu 4,27. Begitu juga dengan pemanfaatan internet untuk kegiatan penyuluhan penyadaran masalah memiliki rataan skor sebesar 3,75. Pemanfaatan internet untuk kegiatan penyuluhan analisis situasi serta motivasi dan keterampilan memiliki rataan skor yang sama yaitu sebesar 3,61, dan juga pada kegiatan pengambilan keputusan menunjukkan angka rataan skor yang tidak jauh berbeda dengan kegiatan analisis situasi serta motivasi dan keterampilan yaitu sebesar 3,65. Secara keseluruhan, responden 
sudah memanfaatkan internet untuk mendukung seluruh tugas penyuluh pertanian walaupun masih dalam kategori kadang dan intensitas yang tidak banyak, ditunjukkan dengan total rataan skor yaitu 3,77 .

Tabel 7 Persentase dan rataan skor responden menurut pemanfaatan internet dalam penyuluhan pertanian

\begin{tabular}{llcccc}
\hline \multirow{2}{*}{ Kegiatan Penyuluhan Pertanian } & \multicolumn{3}{c}{ Persentase \% } & \multirow{2}{*}{ Rataan Skor* } \\
\cline { 3 - 5 } & $\begin{array}{c}\text { Tidak } \\
\text { Pernah }\end{array}$ & Rendah & Tinggi & \\
\hline 1. & Analisis situasi & 28,9 & 42,1 & 28,9 & 3,61 \\
2. & Penyadaran masalah & 36,8 & 28,9 & 34,2 & 3,75 \\
3. & Meningkatkan pengetahuan & 44,7 & 10,5 & 44,7 & 4,27 \\
4. & Pengambilan keputusan & 28,9 & 44,7 & 26,3 & 3,65 \\
5. & Motivasi dan keterampilan & 26,3 & 39,5 & 34,2 & 3,61 \\
\hline & Total & - & - & - & 3,77 \\
\hline
\end{tabular}

*kisaran skor 1-6

\section{Pemanfaatan Internet dalam Analisis Situasi}

Internet menyediakan berbagai macam informasi salah satunya dapat dimanfaatkan oleh penyuluh untuk mencari informasi mengenai wilayah kerja mereka, dengan kata lain internet dapat dimanfaatkan oleh penyuluh untuk menganalisis situasi. Rataan skor yang didapatkan dari indikator ini yaitu 3,61 hal ini dikarenakan masih terdapat responden yang kurang percaya dengan informasi yang ada diinternet.

\section{Pemanfaatan Internet dalam Penyadaran Masalah}

Manfaat internet selain untuk menambah wawasan adalah untuk berkomunikasi dan membina hubungan dengan dunia luar. Internet dapat dimanfaatkan oleh penyuluh untuk mendukung kegiatan penyuluhan, yaitu penyadaran masalah. Pemanfaatan internet untuk mendukung kegiatan penyuluhan penyadaran masalah masih dalam kategori tidak pernah. Hal ini dapat dilihat pada rataan skor yang terdapat pada pemanfaatan penyadaran masalah ini yaitu sebanyak 3,75. Hal ini dikarenakan keinginan responden untuk membantu petani dalam menyadarkan masalah lewat internet masih sedikit dan masih menggunakan cara konvensional dengan mengumpulkan petani di balai penyuluhan dan melakukan kegiatan rembukan bersama.

\section{Pemanfaatan Internet dalam Meningkatkan Pengetahuan}

Penyuluh yang posisinya paling dekat dengan petani dituntut untuk terus mengembangkan pengetahuan yang mereka miliki demi tercapainya pembangunan pertanian dan juga demi memajukan dan memberdayakan petani. Berbagai macam informasi mengenai pertanian bisa didapatkan salah satunya melalui internet kemudian menyampaikannya ke petani. Rataan skor pada kegiatan ini, menunjukkan jumlah rataan yang paling besar diantara indikator yang lain, yaitu sejumlah 4,27. Secara keseluruhan, responden sudah memanfaatkan internet untuk membantu petani meningkatkan pengetahuan, salah satunya dengan mencarikan informasi yang dibutuhkan petani lewat internet.

\section{Pemanfaatan Internet dalam Pengambilan Keputusan}

Penyuluh memfasilitasi petani untuk membantu petani memutuskan pilihan yang tepat, dengan kata lain penyuluh berperan di dalam proses pengambilan keputusan. Internet dapat dimanfaatkan oleh penyuluh salah satunya untuk mendukung kegiatan penyuluhan ini, mengingat manfaat internet salah satunya sebagai media untuk berkomunikasi dan mengumpulkan informasi. Rataan skor yang didapatkan dari indikator ini juga menunjukkan angka sejumlah 3,65 hal tersebut dikarenakan intensitas komunikasi antara penyuluh dan petani melalui 
internet masih sedikit. Dalam proses pengambilan keputusan membutuhkan forum diskusi, setiap balai penyuluhan sudah dilengkapi dengan facebook tujuannya agar memudahkan petani apabila memiliki keluhan dan dapat langsung didiskusikan oleh para penyuluh. Tetapi pada kenyataannya, hal tersebut tidak berjalan sesuai dengan yang diharapkan, karena keterbatasan petani dalam hal akses internet. Maka dari itu pemanfaatan internet untuk mendukung kegiatan pengambilan keputusan masih terbilang rendah.

\section{Pemanfataan Internet dalam Motivasi dan Keterampilan}

Tugas seorang penyuluh selain untuk menambah pengetahuan petani, penyuluh juga bertugas untuk meningkatkan motivasi petani dan keterampilan petani dalam suatu bidang tertentu. Salah satu cara untuk tetap memotivasi dan meningkatkan keterampilan petani, penyuluh dapat memanfaatkan internet. Rataan skor yang didapatkan dari indikator ini adalah 3,61 hal tersebut menunjukkan bahwa responden sudah memanfaatkan internet walaupun masih dalam kategori rendah dengan intensitas yang tidak banyak. Komunikasi yang baik dibutuhkan dalam hal pemberian motivasi kepada petani. Pada kenyataannya, tidak semua penyuluh pernah melakukan komunikasi dengan petani melalui internet karena hanya sebagian kecil petani yang sudah dilengkapi dengan fasilitas internet. Maka dari itu, pemanfaatan internet untuk mendukung kegiatan ini belum dimaksimalkan oleh responden.

\section{Hubungan Perilaku Penggunaan Internet dengan Pemanfaatan Internet}

Hubungan antara perilaku penggunaan internet dengan pemanfaatan internet dianalisis dengan menggunakan koefisien Rank Spearman ditunjukkan pada Tabel 8.

Hasil uji Rank Spearman pada Tabel 8 secara keseluruhan menunjukkan hasil nilai koefisien korelasi pada tingkat korelasi rendah $\left(\gamma_{\mathrm{s}}=0,30-\right.$ $0,50)$ dan korelasi sedang atau moderat $\left(\gamma_{\mathrm{s}}=0,50\right.$ $-0,70)$

Dapat dilihat pada Tabel 8 sebagian besar menunjukkan hasil hubungan sangat nyata $(\mathrm{p}<$ $0,01)$. Hubungan sangat nyata $(\mathrm{p}<0,01)$ antara perilaku penggunaan internet dengan kegiatan penyuluhan pertanian ditunjukkan pada hubungan antara indikator frekuensi dengan indikator analisis situasi, pengambilan keputusan, serta motivasi dan keterampilan. Hubungan sangat nyata lainnya yaitu antara indikator durasi dengan seluruh indikator kegiatan penyuluhan pertanian. Semakin tinggi frekuensi dan durasi responden menggunakan internet, maka semakin tinggi pula pemanfaatan internet yang dilakukan oleh responden untuk mendukung kegiatan tersebut. Hal tersebut dikarenakan sebagian besar responden sudah menyadari bahwa internet merupakan suatu media yang dapat dimanfaatkan untuk mendukung pekerjaan mereka sebagai penyuluh pertanian yang bertugas untuk memfasilitasi petani.

Korelasi rendah $\left(\gamma_{\mathrm{s}}=0,30-0,50\right)$ terlihat pada hubungan antara frekuensi dengan penyadaran masalah, meningkatkan pengetahuan, dan pengambilan keputusan. Korelasi rendah juga terlihat pada hubungan antara durasi dengan penyadaran masalah, meningkatkan pengetahuan, dan pengambilan keputusan. Korelasi sedang $\left(\gamma_{\mathrm{s}}=0,50-0,70\right)$ terlihat pada hubungan antara frekuensi dengan analisis situasi dan motivasi dan keterampilan.

Tabel 8 Nilai koefisien korelasi Rank Spearman berdasarkan hubungan antara perilaku penggunaan internet dengan pemanfaatan internet dalam penyuluhan pertanian

\begin{tabular}{lccccc}
\hline Perilaku & \multicolumn{4}{c}{ Kegiatan Penyuluhan Pertanian } \\
\cline { 2 - 6 } Penggunaan & Analisis & Penyadaran & Meningkatkan & Pengambilan & Motivasi dan \\
Internet & Situasi & Masalah & Pengetahuan & Keputusan & Keterampilan \\
\hline Frekuensi & $0,541^{* *}$ & $0,370^{*}$ & $0,429^{*}$ & $0,415^{* *}$ & $0,593^{* *}$ \\
Durasi & $0,615^{* *}$ & $0,489^{* *}$ & $0,490^{* *}$ & $0,416^{* *}$ & $0,525^{* *}$ \\
\hline
\end{tabular}

$*=$ hubungan nyata $(\mathrm{p}<0,05)$ dan $* *=$ hubungan sangat nyata $(\mathrm{p}<0,01)$ 
Korelasi sedang juga terlihat pada hubungan antara durasi dengan analisis situasi dan motivasi dan keterampilan. Pemanfaatan internet untuk mendukung kegiatan penyuluhan analisis situasi serta motivasi dan keterampilan perlu lebih lama menggunakan internet karena untuk mendukung kegiatan tersebut membutuhkan informasiinformasi baru dan salah satunya dapat dicari melalui internet. Berbeda dengan kegiatan penyuluhan lainnya yang bisa dipenuhi dengan cara pendekatan personal antara penyuluh dengan petani, jadi tidak perlu menggunakan internet lebih lama untuk mendukung kegiatan tersebut. Maka dari itu korelasi yang menunjukkan angka yang paling besar adalah korelasi antara perilaku penggunaan internet dengan kegiatan penyuluhan analisis situasi dengan kegiatan penyuluhan motivasi dan keterampilan.

Hasil pengujian membuktikan bahwa perilaku penggunaan internet berhubungan sangat nyata dengan pemanfaatan internet untuk mendukung kegiatan penyuluhan pertanian. Hipotesis terakhir yang berbunyi "terdapat hubungan antara perilaku penggunaan internet dengan pemanfaatan internet oleh penyuluh pertanian" diterima.

\section{SIMPULAN DAN SARAN}

\section{Simpulan}

Penyuluh pertanian cenderung sudah cukup memahami mengenai internet walaupun masih dalam kategori paham sebagian atau hanya sekedar mengetahui mengenai internet. Penyuluh pertanian sudah cukup memahami mengenai pengertian internet, fungsi internet, media untuk mengakses internet, teknis menggunakan internet, dan juga penggunaan internet.

Frekuensi penyuluh pertanian saat menggunakan internet masih tergolong rendah yaitu sebanyak dua sampai tiga kali dalam sehari. Serta durasi menggunakan internetnya pun masih tergolong rendah yaitu sebanyak satu sampai dua jam dalam sehari. Hal tersebut dikarenakan tugas penyuluh pertanian menyita waktu lebih banyak sehingga waktu yang digunakan penyuluh pertanian untuk menggunakan internet tergolong rendah.
Penelitian ini menunjukkan bahwa penyuluh pertanian sudah cukup memanfaatkan internet untuk mendukung kegiatan penyuluhan pertanian walaupun masih tergolong dalam kategori kadang. Hal tersebut dikarenakan penyuluh masih melakukan tugas-tugasnya dengan cara tatap muka dengan petani.

\section{Saran}

Internet dapat dimanfaatkan sebagai media untuk mendukung kegiatan penyuluhan pertanian demi tercapainya pembangunan pertanian.

Penyuluh pertanian sebagai tenaga terdidik dapat melatih petani mengenai internet, agar petani dapat mengakses internet dan juga dapat memudahkan para penyuluh dalam melaksanakan tugas-tugas sebagai penyuluh pertanian jika para petaninya pun bisa mengakses internet.

\section{DAFTAR PUSTAKA}

Andina, HP. 2006. Pola Penggunaan Internet dan Dampaknya terhadap Remaja [skripsi]. Bogor (ID): Institut Pertanian Bogor.

Ardianto E, Komala L, Karlinah S. 2014. Komunikasi Massa Suatu Pengantar Edisi Revisi. Bandung (ID): Simbiosa Rekatama Media.

Bungin MB. 2008. Sosiologi Komunikasi: Teori, Paradigma, dan Diskursus Teknologi Komunikasi di Masyarakat. Jakarta (ID): Kencana Prenada Media Group.

Hafsah MJ. 2009. Penyuluhan Pertanian Di Era Otonomi Daerah. Jakarta (ID): PT. Pustaka Sinar Harapan.

Melha TV. 2012. Motivasi Penggunaan Facebook dan Pemenuhan Kebutuhan Afiliasi pada Remaja Pedesaan [skripsi]. Bogor (ID): Institut Pertanian Bogor.

Mugniesyah SS. 2006. Ilmu Penyuluhan. Bogor (ID): Institut Pertanian Bogor.

Muljono P. 2005. Pemanfaatan Internet sebagai Media Komunikasi di Indonesia [studi pustaka]. Bogor (ID): Institut Pertanian Bogor.

Nirmala IY. 2006. Pemanfaatan Internet dan CD ROM oleh Peneliti dan Perekayasa [tesis]. Bogor (ID): Institut Pertanian Bogor.

Pambudy R, Yasa IM, Adhi AK, Siagian B, Sahidu A, Riyanto S, Marzuki, Tariningsih 
D, Soemardjo, Buhanuddin. 1996. Implementasi Pola Penyuluhan Pertanian di DKI Jakarta. Kerjasama Badan Perencanaan Pembangunan Daerah (BAPPEDA) Daerah Khusus Ibukota Jakarta dengan Pusat Studi Pembangunan Lembaga Penelitian Institut Pertanian Bogor (ID).

Permatasari SUD. 2012. Pemanfaatan Teknologi Komunikasi dan Informasi oleh Penyuluh Pertanian [skripsi]. Bogor (ID): Institut Pertanian Bogor.

Rakhmat J. 2003. Psikologi Komunikasi. Bandung (ID): PT Remaja Rosdakarya.

Severin WJ, Tankard JW. 2011. Teori Komunikasi: Sejarah, Metode, \& Terapan di Dalam Media Massa, Edisi Ke-5. Hariyanto S, penerjemah. Jakarta (ID): Kencana Prenada Media Group.

Singarimbun M. 1989. Metode Penelitian Survai.Singarimbun M, Effendi S, editor. Jakarta (ID): LP3ES.

Wirawan SS. 1999. Psikologi Sosial: Individu dan Teori-Teori Psikologi Sosial. Jakarta (ID): Balai Pustaka.

Yusup PM. 2009. Ilmu Informasi, Komunikasi, dan Kepustakaan. Jakarta (ID): PT Bumi Aksara. 